\title{
Increasing Vocabulary Mastery by Using Song- Related Reading Texts to Children Aged Six to Twelve
}

\author{
W Wahyudi* \\ English Graduate Department \\ Post Graduate Program \\ University of Mataram \\ Indonesia \\ wahyudi46ok@gmail.com
}

\author{
Kamaludin Yusra \\ English Graduate Department \\ Post Graduate Program \\ University of Mataram \\ Indonesia
}

\author{
A Amrullah \\ English Graduate Department \\ Post Graduate Program \\ University of Mataram \\ Indonesia
}

\begin{abstract}
The purpose of this research examines an effective and innovative way of increasing the English vocabulary of children aged six to twelve years old children in Batu Raja Village Mataram West Nusa Tenggara. They were in grade 1 to 5 of different elementary schools participating in a private English Home Class. The study were conducted in the following procedure: (a) teacher-student greetings (b) brainstorming activities, (c) students' listening to a song, (d) teacher and student singing the song, (e) reading a songrelated text, (f) students interact with text through question and answer activities. The result proves that the children's ability to comprehend word meaning reaches the minimum required standard competency and they can write, spell and use the words in spoken forms. In addition, the children are motivated to learn English by singing the songs and memorize each the words that they have learned (from ten words most of children memorized eight to nine words). This result shows facilitating role of songs for mastering English words. In addition, the children enjoy each word that they have learned by singing them in every place and moment that they have. The value of giving the children reading texts can prove that this way is an effective way of introducing fun and enjoyable English lessons to beginning learners of English.
\end{abstract}

Keywords—vocabulary, innovation, teaching, reading, standard

\section{INTRODUCTION}

Viewing the phenomenon of children in learning English especially for children aged six to twelve years old in Batu Raja Village Mataram West Nusa Tenggara, then this research focuses on increasing the vocabulary mastery for children in the early aged English learning. Before describe the focus of this research, it will be better to describe the notion of children under 14 years old aged. The describing of children in under of 14 years old is related to the object of this study, which children between aged 5 to 12 years old. According to [1] Young learners are children between the ages about 5 years old to 12 years old.Therefore, an understanding about young learner in this research is children who related to the age of the children sampling as participant were in class 1 to 5 of various elementary school in Batu Raja Village Mataram who has aged in six to twelve years old. Why should this research conducted to the children who have aged six to twelve, because it is better for the children knowing English as their second language in early aged.

Teaching vocabulary for children is very important because learning English vocabulary will help the children mastering the language. Based on [2] stated, a large vocabulary is required for someone to use language in a desired manner. Then, this study conducted to use songrelated reading text to increase the children's vocabulary in learning English. In this case there are some procedure conducted in the learning process of increasing children's vocabulary by using song-related reading text as follows: (a) teacher-student greetings (b) brainstorming activities, (c) students' listening to a song, (d) teacher and student singing the song, (e) reading a song-related text, (f) students interact with text through question and answer activities.

Teaching English to Young Learner in this research related to the age of six to twelve years old children, and introducing English to the beginning young learners is very important. Vocabulary will help the student maintain their ability in learning language, as [2] stated, a large vocabulary is required for someone to use language in a desired manner. In increasing the children's vocabulary in their beginning learning English, teacher must modify the method of how to teach children to have them with fun learning situation. Focusing to this research, there are some of component that must clearly illustrated, which are; Vocabulary, Song and Reading text as role of a context in increasing the children's vocabulary.

Vocabulary is kind of word groups in study languages, especially in study English there are kind of words; noun, verb, adjective and adverb. As [3] stated that vocabulary is central to language teaching. [4] stated that all languages consist of words, languages emerges first as words, both historically, and in terms of the way each of us learned our first and any subsequent languages. Therefore, in Teaching English to You Young Learners especially in aged six to twelve years old is very important for the children as their Second Language. Studying vocabulary for children can be a challenge for them. As [5] stated the learner while learning the vocabulary of a second language can come across several challenges: Making the correct connections, when understanding the second language, between the form and meaning of words. When producing language, using the 
correct form of a word for the meaning intended (i.e. nose not noise).

To meet these challenges the learner needs to: Acquire a critical mass of word for use in both understanding and producing the language, remember words over time, be able to recall the readily, develop strategies for coping with gaps in word knowledge, including coping with unknown words, or unfamiliar uses of known words, and have to take responsibility themselves for vocabulary expansion.

Related to the challenges, children need to be taught with more interesting material arrangement to increase their vocabulary, one of the ways by giving the children material that is related to song and reading text to memorize each word that they studied.

Reading text has a very important role in Teaching English to Young Learner especially in increasing vocabulary. [6] stated that reading is useful for other purposes too; any exposure to English (provided students understand it more or less) is a good thing for language students, and Jeremy Harmer also stated that reading texts also provide opportunities to study language; vocabulary, grammar, punctuation, and the way we construct sentences, paragraph and text.

In this research reading text is related to the song, the role of reading text that related to the song is to let the children memorize and comprehend the words given since the learning process were running in every meeting.

The role of song in increasing children's vocabulary is making the material of memorizing words more interest. Why song? Song can be interesting to the children, because children like to sing, and children enjoy singing and they will have a good respond to sing song. According to [7], using song can also give learners the opportunity to acquire a better understanding of the culture of the target language. So that's why song has an advantage in running the learning process of Teaching English to Young Learner in early aged. [8] stated that most obvious advantage to using songs in the young learner classroom is that they are enjoyable. Most children enjoy singing and usually respond well to using songs in the class, but there are more significant benefits to using songs other than just being fun.

Introducing song to children and letting children singing songs will help the children memorize each word that they have studied, because the children repeat the words every time they sing it. [9] stated that the children practice saying the words in the same way they sing the song, the children can repeat the words in rhythmic word groups. Therefore, it can be said that song can help children increasing their vocabulary because they would enjoy to sing and memorize the words every time they sing the songs.

\section{METHODS}

This study used quantitative method, because this study is an experimental. The data from the test given is the data achievement score from both "pre-test and post-test"and the test is applied before the treatment and after using songrelated reading text". Based on the test, this study conducted to investigate whether by using song-related reading text in increasing children's vocabulary in aged six to twelve years old is an effective way to mastery English vocabulary rather than only use dictionary. Then the investigation method is using questionaire that will be on computing tabulation.

\section{A. Research Planning}

This research conducted in private English Home Classes. The class has two meetings in a week and in every meeting children got different material (song-related reading text). Teaching and learning processes consist of any topic and songs to find the target of increasing children's vocabulary.

\section{B. Participant}

The numbers of student in this study are 25 children aged from six to twelve year old used as the sample of the study. They were in grade 1 to 5 of different elementary schools in Mataram, West Nusa Tenggara.

\section{Learning Activity}

The material in this study is used for every meeting almost different, because the children were interested to the activity. When the classroom is running, the children involved to the procedure of its process: First, teacherstudent greetings; in this part teacher giving the children the difficult words and the difficult words are related to the song-related text as their new vocabulary. Second, brainstorming activities; in this activity, teacher asked the children to spell and speak each of the difficult given in an instruction of teacher. Third, students' listening to a song; teacher let the children listen to the song, in this activity, teacher may sing the song and the children heard and comprehend the song. Fourth, teacher and student singing the song; teacher and the children singing the song by guiding of teacher in interpret the songs' chant until the student completely knowing and the student sing it again in repetition together with their friend, teacher also may use an instrument. Fifth, reading a song-related text; children instructed to read a text-related a song, kind of a text arranged by teacher in a short story form and the context is related to the song. Sixth, students interact with text trough question and answer activities; in this activity, student answered a number of questions related to the text and song, the goal of answering the question to knowing the whether the children already known a number of every words given.

From the procedure of the activities prove that the children able to comprehend word meaning and the children can write, spell and use the words in spoken forms. In addition, the children are motivated to learn English by singing the songs and memorize each the words that they have learned. It can be proved that by giving the-reading texts which are related to songs, the children will be facilitated in understanding and comprehending English words, and the children enjoy each word that they have learned by singing them in every place and moment that they have. The value of giving the students the reading texts prove that this way is an effective way of introducing fun and enjoyable English lessons to beginning learners of English.

\section{Data Collection}

The data in this research involves scores of pre-test, posttest and the questionnaire perceptions on using using song related - reading text in increasing vocabulary mastery. 


\section{E. Data Analysis Procedures}

The analysis procedures are beginning from both data pre-test and post-test collected. The first data are before using song-related reading text, where pre-test used to the suitable words related to the children's ability before the children involved to the learning processes by using songrelated reading text. The second data are after using songrelated reading text, where post-test used to the suitable words related to the children's ability after involved to the learning processes by using song-related reading text. The number of words for both pre-test and post-test are questioned to the children by pear the word meaning given in a test paper about 80 words by 1,25 scored for each correct answer

\section{RESULTS AND DISCUSSION}

Researcher presents the importants analysis as the result of data collectios. They are the analysis of pretest, postest and the analysis of questionnaire based on the implementation of using song related - reading text in increasing vocabulary mastery to the children aged six to twelve. The comparison score of the tests to prove whether using song-related reading text in this study applied two times of tests. First, test for pre test score to indicate children's vocabulary before the treatment of using songrelated reading text. Second, test for post test score after the treatment of using song-related reading text in increasing children's vocabulary. Both of these tests will indicate that the effective and innovative way in teaching English to Young Learner especially children in aged six to twelve years old by using song-related reading text have significant differences before and after using song-related reading text. Then it has been proved by the $t$-test computation that this way based on observed value proved that using song-related reading text is an innovative way in teaching children vocabulary, because the children interested to that way. Students are not only increase their vocabulary but they are also can write, spell and use the words in spoken forms

\section{A. Findings}

The data in this research is the data collected. There are the achiement scores of pretest, posttest and form the questionnaire respond that the children responded toward the activity of using song related - reading text in increasing vocabulary mastery.

Finding the standard ability of children on mastering vocabulary, then this study examined the childrens' ability by giving them test. The data is gahtered for this study is the achievment of test. The correct answer of test is the data that will be identified the children knows the meaning of the words they got before treatment of using song related reading text in increasing vocabulary mastery. The children asked to read and spelling the words given and guided the reseacher and the children pair the correct meaning to Indonesia languages.

The researcheer asked the children by pear the word meaning given in a test paper about 80 words by 1,25 scored for each correct answer. The total and mean achievement or score that the children got as following:

TABLE I. THE TOTAL AND MEAN OF CHILDRENS' PRE-TEST ACIEVEMENT

\begin{tabular}{|c|c|c|}
\hline Total & 1490 & $1490.00 \%$ \\
\hline Mean & 59.6 & $59.60 \%$ \\
\hline
\end{tabular}

The data above showed the total score of all childrens' achievement is 1490 and $1490.00 \%$ for the total of all children's precentage. The mean of pretest is $59,60 \%$ which is indicated the children have standard ability in mastery English vocabulary. It is showed that the children familiar enough with English vocabulary where they can read and comprehenced the words meaning.

The measurement of posttest achievement score proved that the childrens' ability on mastering English vocabulary is significant after the treatment of inreasing vocabulary mastery by using using song-related reading text to children aged six to twelve years old.

The data is gahtered for this study is the achievment of post test. The correct answer of post test is the data that will be identified whether the children knows the meaning of the words that they got after treatment of using song related reading text in increasing vocabulary mastery. The children were asked to answer the words given and researcher guided the children paired the correct meaning words to Indonesia language. The researcher asked the children by pear the word meaning given in a test paper about 80 words by 1 , 25 scored for each correct answer. The achievement or score that the children got as following below:

TABLE II. THE TOTAL AND MEAN OF CHILDRENS' Post Test ACHIEVEMENT

\begin{tabular}{|c|c|c|}
\hline Total & 2158.75 & $2158.75 \%$ \\
\hline Mean & 86.35 & $86.35 \%$ \\
\hline
\end{tabular}

The data above showed the total score of all childrens' achievement is 2158.75 and $2158.75 \%$ for the total of all children's precentage. The data above showed the average achievement of the children's posttest was $86.35 \%$ which is indicated that the children have significant increasing achievement percentage. It is showed that the children have increasing achievement on their ability in increasing vocabulary mastery by using song related reading text. The children can read and comprehenced the words meaning.

\section{B. The Analysis of Data}

The data gathered in this study is find the mean of pretest and post-test and standard deviation is formulated to answer research question of this study; "is the use of song related reading text effective for teaching and increasing children's mastery of English vocabulary?" Then the testing hypothesis of Songs-Related Reading Text (SRRT) consist of first and second null hypothesis $\left(\mathrm{Ho}\right.$ and $\left.\mathrm{H}_{1}\right)$ which formulated to disprove the hypothesis. The step of testing the hypothesis started from the procedures, which are; testing hypothesis, determine the alpha score, determine statistical testing, and determine the disprove of Ho by $\mathrm{t}-$ computing and t-table, as the formulation bellow:

Ho is contrast or disprove if (t-computing) > t-table: [t-computing] $=[-4,4993]=4,4993$ $\mathrm{t}$-table $=2,0639$

[t-computing] > t-table the Ho is contrast of disprove

The formula above shown the contrast Ho (null hypothesis) where the score of t-computation is more than 
the score of t-table. It means; if the absolute value of tcomputing is 4,4993 and greater than the value of $t$-table is 2,0639. It means the result of correspondent is inequality. Because of, the value of Ho is rejected, so, that means the value of $\mathrm{H}_{1}$ is accepted. And it is proved that there is a significant differences statistical value to increasing the children's mastery vocabulary by using song-related reading text.

\section{The Analysis of Data Questionnaire}

The tabulating of data questionnaire in this research is to describe the result of grading and determine the questionnaire statements scale score, where the table consist of the achievement of scale of the questionnaire, which are presented as follows:

TABLE III. THE CRITERION AND CATEGORY ON POINT OF SCALED MEANING

\begin{tabular}{|c|c|c|c|c|}
\hline \multicolumn{2}{|c|}{ Criterions } & \multicolumn{3}{c|}{ Category } \\
\hline Indicator & Meaning & \multicolumn{2}{|c|}{ Point of Scale } & Meaning \\
\hline 1 & Strongly Disagree & 1.00 & 1.80 & Not Very Good \\
\hline 2 & Not Agree & 1.81 & 2.60 & Not Good \\
\hline 3 & Disagree & 2.61 & 3.40 & Deficiently Good \\
\hline 4 & Agree & 3.41 & 4.20 & Good \\
\hline 5 & Strongly Agree & 4.21 & 5.00 & Very Good \\
\hline
\end{tabular}

TABLE IV. THE INDEX’S OF STATEMENT ITEM

\begin{tabular}{|c|c|c|}
\hline Statement's Item & Index & Category \\
\hline You are feel happy to study English using song-related reading text based on the topic & 3.88 & Good \\
\hline By singing song and reading text can increase your spirit to learn English & 3.76 & Good \\
\hline By English Children's song and short reading text can increase your vocabulary & 3.84 & Good \\
\hline By singing song related reading text can help you translate and remember the meaning of the words & 3.80 & Good \\
\hline $\begin{array}{c}\text { You can comprehended and understand every difficult words on each material that is given by your facilitator } \\
\text { or your teacher }\end{array}$ & 3.76 & Good \\
\hline You can comprehended English vocabulary learning using song-related reading text, easily. & 3.80 & Good \\
\hline $\begin{array}{c}\text { You are feel happy singing English for Children Song, therefore you can remember, speech English words, } \\
\text { and motivated. }\end{array}$ & 3.76 & Good \\
\hline $\begin{array}{l}\text { In out of teaching and learning class, you singing English for Children Song and you comprehended each of } \\
\text { words meaning for every song that you sing. }\end{array}$ & 3.40 & Deficiently Good \\
\hline The vocabulary mastery is very effective delivered by song related reading text. & 4.04 & Good \\
\hline Average & 3.78 & Good \\
\hline
\end{tabular}

Concluding the result of questionnaire mean is tabulated based on the data found, and it will be matching with the criterion and the category of the despondence replay. The details information about the conclusion of questionnaire result can be seen in the tabulation table IV. Concluding the result of questionnaire mean is tabulated based on the data found, and it will be matching with the criterion and the category of the despondence replay, as follows:

1. Children's interest; children feel happy to study English using song-related reading text based on the topic

2. Enthusiastic; by singing song and reading text can increase the children spirit to learn English

3. The Advantages; by English Children's song-related reading text can increase children's vocabulary

4. Translation; by singing song-related reading text can help you translate and remember the meaning of the words

5. Comprehension; children can comprehend and understand every difficult words on each material that is given by their facilitator or teacher.

6. Agility; children can answer questions in "Match the Words in to Indonesia Form" related to the material given, easily.

7. Sustainability; children can comprehend English vocabulary learning using song-related reading text, easily.

8. Motivation; the children feel happy singing "English for Children Song", therefore they can remember, speech English words, and motivated.
9. Relevancy; in out of learning class, children singing "English for Children Song" and the children comprehended each of word meanings for every song that they sing.

10. Effectiveness; the children fell that increasing vocabulary mastery is very effective delivered by song-related reading text.

The step of tabulating questionnaire above described that the effectiveness of increasing vocabulary mastery by using song-related reading text is effective. The objective of the questionnaire resulted that the average of the index achievement score are 3.78 in category "good", and it is proved that by song-related reading text to increase children's vocabulary mastery is an effective way.

\section{Discussion}

The interpretation of research finding will explained the data found based on the formulation that this research deal with and it will give the limitation of the study.

\section{The Analysis of Pre Test}

As it was described in the research methods and in part of research findings. The Pre-test was conducted on first meeting, and the number of children are 25 childrens, and they involved to answer the test in " $\mathrm{M}$ atch the Words" meaning into Indonesia language. The words that the childrens answered are 80 words by 1.25 scored for one correct answer.

The achievement or score that the children got form the pre-test conducted was very varied. The data showed the mean or average scored of pre-test is 59.6. Then this research formulated the percentage of the average score was 59.50 and 
it indicated that the children was familiar enough with English, where they can read and comprehended the words meaning.

\section{The Analysis of Post Test}

The post test was conducted on last meeting and the number of children are 25 childrens. The data is gahtered for this study is the achievment of post test. The correct answer of post test is the data that will be identified whether the children knows the meaning of the words that they got after treatment of using song related reading text in increasing vocabulary mastery. The children were asked to answer the words given and researcher guided the children paired the correct meaning words to Indonesia language.

The researcheer asked the children by pear the word meaning given in a test paper about 80 words by 1,25 scored for each correct answer. The achievement or score that the children got from the post test was a very significant result, where the data showed the mean or the average score of the post test conducted are 86,35 then this research formulated the percentage of the average score was $86.35 \%$. It indicate that the children have increasing achievement on their ability in increasing vocabulary mastery by using song related reading text. The children can read and comprehenced the words meaning.

\section{The Analysis of Post Test}

The post test was conducted on last meeting and the number of children are 25 childrens. The data is gahtered for this study is the achievment of post test. The correct answer of post test is the data that will be identified whether the children knows the meaning of the words that they got after treatment of using song related reading text in increasing vocabulary mastery. The children were asked to answer the words given and researcher guided the children paired the correct meaning words to Indonesia language.

The researcheer asked the children by pear the word meaning given in a test paper about 80 words by 1,25 scored for each correct answer. The achievement or score that the children got from the post test was a very significant result, where the data showed the mean or the average score of the post test conducted are 86,35 then this research formulated the percentage of the average score was $86.35 \%$. It indicate that the children have increasing achievement on their ability in increasing vocabulary mastery by using song related reading text. The children can read and comprehenced the words meaning. Some difficulties found when the childrens' answer to pair the words with its match meanings to Indonesia language, such as; wonder, ought to, fleece, against, turned, patiently, shrugged, stream, boarded, announced. However the difficulties that the children found, it is proved that the children have a significant rising ability in increasing their vocabulary bay using song related reading text.

\section{The Analysis of Questionnaire}

The data found in this research related to the questionnaire given and the children answer ten statements in the questionnaire. Where the data will be formulated with certain techniques to analysis the result of children respondent. Grading and determining the data that consist of ten statements on its criterion was scaled into the category; Very Not Good, Not Good, Deficiently Good, Good and Very Good category score.
The tabulating of data questionnaire describe the result of grading and determine the questionnaire statements scale score, where the table consist of the achievement of scale of the questionnaire, and it giving more information related to the questionnaire response from the children. Then matched of the mean on each questionnaire's statement item. And it will be the mean category to the score of questionnaires resulted, which the analysis of the questionnaire result based on the criterion described that the effectiveness of increasing vocabulary mastery by using song-related reading text is effective. The objective of the questionnaire resulted that the average of the index achievement score are 3.78 in "good" category, and it is proved that by using song-related reading text to increase children's vocabulary mastery is an effective way.

\section{CONCLUSION}

Teaching vocabulary for children is very important, because learning English required the children a large number of vocabulary to mastery the language that they learn. The activities procedure of using song-related reading text has been proved that the children able to comprehend word meaning and they can write, spell and use the words in spoken forms. The treatment of singing song and reading text in learning and teaching process let the children to be motivated to learn English. Giving the children song and reading text in this study prove that this way of increasing vocabulary by using songrelated reading text in its activities is one of an effective and innovative way introducing the children in the beginning learning English. The role of song-related reading texts is one of an interesting, effective and innovative way in learning English for young learners. The significant differences of pretest and post-test achievement, where the pre-test is done before the treatment or before taught the children using songrelated reading text. The post test is done after the treatment or taught using song-related reading text. The differences shown from the mean pre-test score is 60 and 86 scored for the post test. That means that there is a significant difference between both values of pre-test and post-test. Based on the questionnaire result, this research proved that the objective effectiveness of Increasing Vocabulary Mastery by Using Song-related Reading text. The step of tabulating questionnaire described that the effectiveness of increasing vocabulary mastery by using song-related reading text is effective. The objective of the questionnaire resulted that the average of the index achievement score are 3.78 in category "good", and it is proved that by song-related reading text to increase children's vocabulary mastery is an effective way.

\section{ACKNOWLEDGMENT}

First of all, researcher would like to express his sincere gratitude for guiding and accomplish this research to the name of listed below:

1. Drs. Kamaludin Yusra, M.A., Ph.D., as the main supervisor for their valuable guidance, suggestion and advice in writing and finished this research, without them this research could not be finish.

2. Dr. Amrullah, M.Pd., as associate supervisor for their valuable guidance, suggestion and advice in writing and finished this research, without them this research could not be finish. 


\section{REFERENCES}

[1] Rixon, Shelagh. (1999). Young Learners of English: Some Research Perspectives. London: Longman.

[2] Schmitt, N.(2010). Researching Vocabulary: A Vocabulary Research Manual. University of Nottingham, UK. pp1-386.

[3] Taylor, Linda. 1990. Vocabulary in Action. New York: Prentice Hall ELT.

[4] Lenka Pribilova (2006). Teaching Vocabulary to Young Learnes. Faculty of Education. Department of English Language and Literature. SMasaryk Univeristy
[5] Scott, Thornbury.2002. How to Teach Vocabulary. New York: Longman

[6] Jeremy Harmer. (1998). How to Teach English. An Introduction to the Practice of English Language Teaching. Longman. England

[7] Jolly, Y. S. (1975). The use of songs in teaching foreign languages. The Modern Language.Journal, 59(1/2), 11-14. http://dx.doi.org/10.2307/325440

[8] Neil T. Millington. (2011). Using Song Effectively to Teach English to Young Learners. Ritsumeikan Asia Pasific University. Japan.

[9] Griffee, Dale T. (1992). Songs in action. UK: Prentice Hall. 